\section{Georg Brandes' jødiske identitet}

affhv. direktor for Dansk Magisterfor-
ening, cand.phil. Arthur Arnheim

$\mathrm{D}$ er har været ført en langtrukken debat om Georg Brandes' tilhørsforhold til det jødiske. Brandes berørte selv forholdet i sin levnedsskildring, og det har siden været omtalt i de store biografier, mest grundigt i Henri Nathansens, ${ }^{1}$ og diskussionen om dette emne er siden fortsat med artikler i såvel danske som udenlandske tidsskrifter. ${ }^{2}$

Både de ældre og de nyere indlæg har benyttet fænomenerne arv og miljø som udgangspunkt for at vurdere, om Brandes' holdninger og litterære produktion var påvirket af hans jødiske afstamning. En mere nutidig vurdering må tage udgangspunkt $i$ et andet fænomen: Identitet eller etnisk identifikation.

De hidtil kendte skriftlige og mundtlige udsagn fra Brandes tyder mere på afstandtagen fra det jødiske end på identifikation med det. Brandes har selv berettet om en episode fra sin barndom, som er meget betegnende. Han fortæller, at han som dreng havde hørt andre drenge bruge ordet jøde, og at han spurgte sin mor, hvad det betød:

"Jøde, sagde Moder smilende, det er nogle Mennesker.

- Stygge mennesker?

- Ja, svarede Moder, sommetider. Undertiden grimme Mennesker, dog ikke altid.
- Kan jeg få en at se?

- Det kan du godt, sagde Moder og løftede mig rask op foran det ovale Spejl, der hang over Sofaen. Jeg udstødte et Skrig, så Moder hurtigt satte mig ned på Gulvet, og jeg viste mig så forfærdet, at Moder fortrød, at hun ikke havde forberedt mig."3

B eretningens sandhedsværdi er tvivlsom. Det er ikke troligt, at den opvakte dreng ikke har hørt ordet jøde eller jødisk nævnt i familiemiljøet, hvor omgangskredsen udelukkende bestod af jøder. Historien har formentlig skullet vise, at Brandes under sin opvækst ikke modtog nogen jødisk påvirkning. Historien har været en del af det forsvarsværk, Brandes byggede op mod kritikeres og polemikeres pukken på, at hans synspunkter, og den måde han fremførte dem på, var udanske og "typisk jødiske".

En anden del af Brandes' forsvar gik ud på at præsentere det jødiske samfund som et religionssamfund og ikke som en del af en nation. Religionen havde han som ateist frigjort sig fra. Det, der stod tilbage, var race-spørgsmålet. Det kunne han - i tråd med tidens opfattelse - ikke frigøre sig fra. Han valgte i stedet at forklare eventuelt jødisk særpræg, og han forklarede det som evner og karaktertræk, erhvervet gennem århundreders kamp mod en fjendtlig omverden.

Fra 1870 og fremefter var jødehadet $\mathrm{i}$ Europa i stadig og stærk vækst. I Østeuropa, hvor der levede flere millioner jøder, førte diskrimination og forfølgelse til, at der skabtes et jødisk flygtningeproblem. Grupper af forfulgte jøder i social nød og armod blev en del af bybilledet rundt om i Europa. Længe før de blev en del af det københavnske bybillede, organiserede 
danske jøder indsamlinger med det mål at bringe de østeuropæiske jøder ud af nødstilstanden og ind $i$ en ny og bedre fremtid. De gjorde det i solidaritet med de ulykkelige. Solidaritet er en del af processen hen imod identifikation.

Hvorledes forholdt Georg Brandes sig til det?

De hidtil kendte udsagn fra Brandes, om de østeuropæiske, jødiske flygtninge, tyder ikke på, at synet af dem påkaldte solidaritet - det var snarere afstandtagen. Han kunne ikke indse, at han havde noget tilfælles med dem. Væmmelsen var lidt af det samme, der kom til udtryk som et skrig i den ovenfor citerede historie, om hvorledes han blev præsenteret for en jøde i form af sit eget spejlbillede. Den kom også frem, da han i 1877 på den schlesiske banegård i Berlin forfærdet så en forhutlet gruppe østeuropæiske, jødiske flygtninge. Hvad Brandes så, var mennesker, som han opfattede stammede fra en helt anden kultur og civilisation, end den han tilhørte.

På en mere betænkelig måde, kom dette også til udtryk i en oplevelse, Brandes fortalte Henri Nathansen om. Under et ophold på kurstedet Karlsbad havde Brandes samkvem med den russiske fyrste Paul Polgorutzki, der havde sagt til ham: "Jeg går ikke ned i byen, jeg vil det ikke, for jeg vil ikke blive antisemit, og jeg kan ikke lade være dermed, ifald jeg går ned og ser disse rædselsfulde jøder." Til hvilket Brandes (i sit brev til Nathansen) føjede: "Jeg forstod ham".

Georg Brandes' afsky for de østeuropxiske jøder holdt sig langt frem i tiden og overskyggede hans gru over deres tilstand. Man skal ikke lade sig vildlede af den omstændighed, at Brandes var med til offentligt skarpt at protestere mod pogromer i Rusland og Polen. Det var en

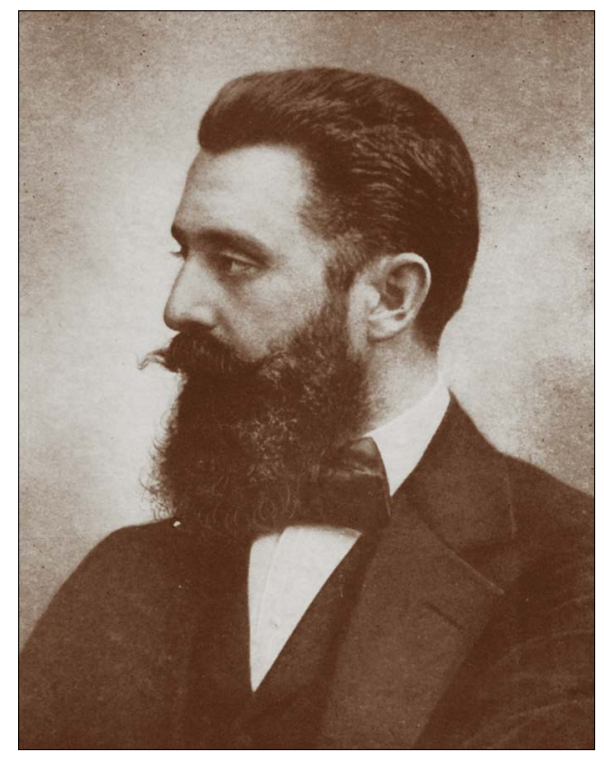

Forfatteren til Der Judenstaat - og dermed zionismens grundlagger - Theodor Herzl. Fra Jacob de Haas: Theodor Herzl. 1927.

indsats for humanitet mod barbari. Om genstanden for diskrimination var jøder eller andre undertrykte minoriteter gjorde formentlig ingen forskel.

I 1896 blev Georg Brandes konfronteret med en anden holdning til "det jødiske problem", som han og mange andre i samtiden opfattede som "de russiske jøders problem".

Udfordringen kom, da Theodor Herzl sendte ham sin lille bog "Der Judenstaat". Ligesom Georg Brandes var Herzl en assimileret, europæisk kosmopolit af jødisk afstamning. Som korrespondent for den førende liberale avis Freie Neue Presse i Wien, havde han i Paris oplevet den bølge af antisemitisme, der havde bredt sig $\mathrm{i}$ Frankrig med udgangspunkt i Dreyfusaffæren. Det medvirkede til, at han generelt tog spørgsmålet op om jødernes situation som spredte minoritetssamfund, 
hvor de var mere eller mindre tålt - men altid i fare, når den latente antisemitisme brød ud i nye forfølgelser. Herzls løsning af problemet var politisk: Der måtte skabes et nationalt hjemsted for jøderne, en jødisk stat. ${ }^{5}$ Ideen var revolutionær. Den brød især med de toneangivende vesteuropæiske jøders selvopfattelse og deres opfattelse af antisemitismen, som fordomme, der ville forsvinde, når det uovervindelige "fremskridt" ville sejre.

"Der Judenstaat" blev trykt i et oplag på 3.000. Heraf reserverede Herzl de 500 til udsendelse til førende intellektuelle ikke-jøder og jøder i Europa. To eksemplarer blev sendt til København, og det ene gik naturligvis til Georg Brandes, der på dette tidspunkt havde indtaget sin plads som ledende europæisk åndspersonlighed.

Der var ikke megen forståelse eller opmuntring at hente for Herzl i Brandes' svar:

"Jeg tvivler på, om man stadig kan kalde Jøder for et Folk. De har ingen fælles Baggrund, ingen fælles Opdragelse, ingen sand Nationalfølelse og de har alle et ikke-jødisk Fædreland, som de - med mere eller mindre Ret - betragter som deres. For mit eget vedkommende har jeg aldrig følt mig som Jøde, selvom jeg ofte er blevet mindet om min jødiske Herkomst ...."

Tyve år senere havde Brandes under indtrykket af den masseudvandring fra Østeuropa, som havde fundet sted i den mellemliggende tid, ændret sin indstilling en anelse. Nu kunne han godt indse, at Palæstina kunne tjene som hjemland for de forfulgte østeuropæiske jøder - underforstået, at zionismen ikke var noget for emanciperede vesteuropæiske jøder.

På ovenstående baggrund må det konkluderes, at der ikke var megen jødisk identitet at finde hos Georg Brandes. Han havde skabt sig en egen identitet med basis i Hellas og den franske revolutions ideer om frihed og lighed. Her var der tilsyneladende ingen plads til en jødisk identitet.

I midlertid er en hidtil ukendt korrespondance (i privateje) dukket op, som giver anledning til at korrigere forståelsen af Georg Brandes' identitet.

Det er en brevveksling fra 1918 mellem Georg Brandes og Herman Heilbuth, der var medlem af Folketinget. Heilbuth havde i mange år været et fremtrædende medlem af Det Radikale Venstre, der på dette tidspunkt havde regeringsmagten.

Den direkte anledning til, at Brandes den 19. august 1918 skrev til Heilbuth, var en opsigtsvækkende - næsten voldelig - konfrontation under et (lukket) udvalgsmøde på Christiansborg mellem nationaløkonomen professor L.V. Birck og den jødiske igangsætter og forretningsmand Max Ballin.

Det var på den tid, hvor der skulle gøres op med "gullasch-baronerne" - et samlet navn for dem, der havde tjent store penge under 1. verdenskrig. Blandt dem var den jødiske industrialist Max Ballin. Han havde revolutioneret garveri- og lædervarebranchen, herunder produktionen af sko og støvler. Det hele var en international udløber af industrialiseringen og dens masseproduktion til forbrugermarkedet og den efterfølgende koncerndannelse. I løbet af 1918 var de store prisstigninger blevet et politisk problem. Under valgkampagnen $i$ april havde professor Birck, der var opstillet af partiet Højre, især slået hårdt ned på Ballins skoproduktion og havde herunder ikke lagt skjul på sine antisemitiske anskuelser. Efter valget 


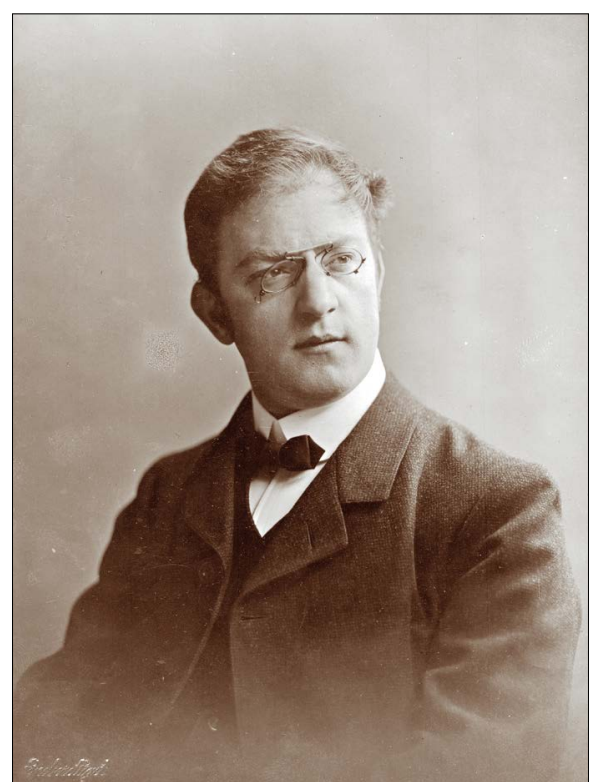

Professor i nationaløkonomi L.V. Birck (1871-1933) sad i en kort periode i Folketinget for Det Konservative Folkeparti, men han var iser kendt for sin indsats i forst Prisreguleringskommissionen (som folge af Første Verdenskrig) og siden Landmandsbankkommissionen i 1920'erne.

nedsatte regeringen den såkaldte Overordentlige Kommission, hvis opgave det var at kontrollere priser og avancer. Birck blev formand for et af kommissionens udvalg, som også Herman Heilbuth blev medlem af. Udvalget ønskede at få indsigt i Ballin-koncernens bogføring. Det førte til et møde på Christiansborg den 6. august 1918. Mødet udviklede sig til en korporlig konfrontation mellem Birck og Ballin. Kulminationen kom, efter at Ballin havde kaldt Birck “Løgner og Æreskænder”. Birck styrtede hen til Ballin, tog ham i kraven, ruskede ham og råbte: "Hvor vover du at tale sådan til mig? Husk, at jeg er en hvid Mand, og du er en Jøde."

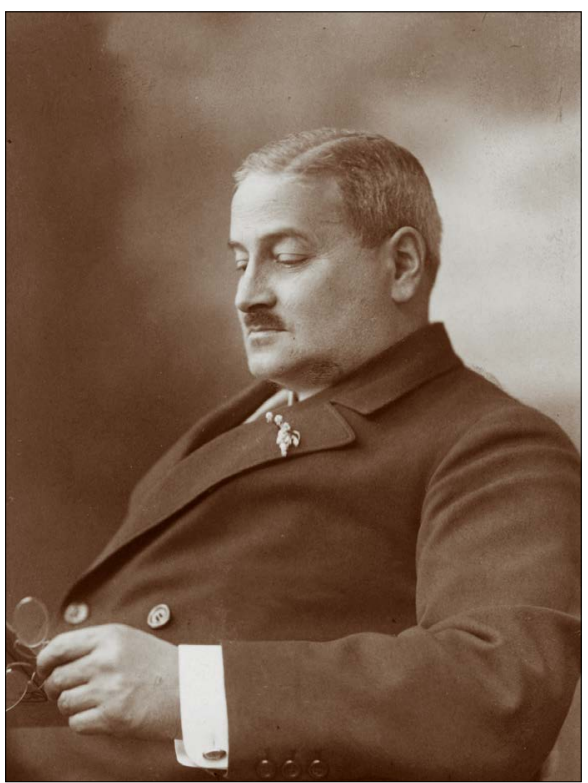

Max Ballin (1865-1921) overtog familiegarveriet $i 1891$ og sad i Industriraddet fra 1909. Gennem vekselererfirmaet Ballin \& Hertz deltog han aktivt $i$ de spekulationer, der forte til Landmandsbankens kollaps i 1922. Han slap dog for retsforfolgelse pga. sin aktivt fremskyndede død arret for.

Episoden vakte stor opsigt, og den fik Brandes til at skrive til Herman Heilbuth:

"Højtærede Hr. Direktør Heilbuth.

Vil De undskylde et Par Linier i en Anledning, der i egentlig Forstand er mig uvedkommende, men i dybere alligevel ikke.

Må det være mig tilladt at udtrykke min Forbavselse over at De tager Sæde i et Udvalg til hvis Formand man vælger Professor L. Birck. Det synes mig ikke at stemme med Deres Værdighed, og det kan let medføre den Opfattelse, at Folk af fremmed israelitisk Afstamning er så vante til at lade sig sparke i Bagdelen Aar- 
tusinder igennem, at de betragter saadan et Spark som en Bagatel det ville være umuligt at tage ilde op.

Jeg skal tilføje, at jeg aldrig har set $\mathrm{Hr}$. Birck. Mit eneste Forhold til ham er, at han i fjor indbød mig til at tilbringe en Aften hos ham med den lige afgaaede hollandske Conseilspræsident, der ønskede at træffe mig, hvilken Indbydelse jeg afslog.

Nu kunne jeg ikke være i Stue med ham. Hvorfor vil De?

Jødehadet er i kraftig Vækst i Danmark som andetsteds. Der maa, synes jeg, være nogen Stolthed overfor det. Men det er ikke stolt at have til Formand en Person, der har betegnet en mig for øvrigt ubekendt Mand som Neger på Grund af hans Afstamning.

Og De synes mig med Deres Holdning at gøre Situationen endnu ulideligere hertillands, end den forud er for adskillige andre, hvoriblandt -

Deres altid hengivne Georg Brandes”

S tillet overfor det, som Brandes i brevet kalder "Jødehadets kraftige Vækst i Danmark" har han søgt at mobilisere jødisk solidaritet og identifikation hos "med-jøden" eller "stammefrænden" Herman Heilbuth. Det er bemærkelsesværdigt, at den Georg Brandes, der

Noter

1 Henri Nathansen: Georg Brandes. En Biografi. 1929.

2 Carl Erik Bay: Georg Brandes som jøde. Fund og Forskning 26, 1982-83 og Kristian Hvidt: Edvard og Georg Brandes' opfattelse af deres jødiske herkomst. Nordisk Tidskrift, ny serie, 1985.

3 Georg Brandes: Levned, I, 1905, s. 20.

4 Carl Erik Bays ovenanførte arbejde, s. $115 f$. tidligere gjorde alt, hvad han kunne for at lægge afstand til, hvad der var jødisk, nu har søgt tilbage til jødisk identitet som et støttepunkt, da antisemitismen begyndte at presse på og blive vedkommende for ham selv.

Endelig skal det bemærkes, at Brandes' opfordring til Heilbuth om i protest at trække sig ud af udvalget, som antisemitten Birck var formand for, var noget ganske usædvanligt. Ledelsen af det danske jødiske samfund indtog den holdning, at man ikke skulle reagere på antisemitiske angreb. Dels troede man på, at jødehadet ville dø ud efterhånden som fremskridt og oplysning trængte igennem, og dels havde man tillid til at regeringen, så at sige med hånden på grundloven, ville beskytte danske jøder mod diskrimination. Brandes forstod og viste med sin opfordring til Heilbuth, at når antisemitisme forkyndes af en intellektuel som professor Birck, der endda havde en politisk platform, så måtte man reagere med handling.

Brandes' kraftige opfordring til Heilbuth har måske også været en reaktion på oplysning om, at der på mødet med konfrontationen mellem Birck og Ballin havde været adskillige andre jøder til stede, der hverken dengang eller senere havde fundet anledning til at reagere.

5 Theodor Herzl: Der Judenstaat. Versuch einer modernen Lösung der Judenfrage. 1896.

6 Rafael Edelman i Judisk Tidsskrift, 1937, s. 84.

7 Georg Brandes: Om Zionismen. Tidsskrift for Jødisk Historie og Litteratur, 1919, s. 135.

8 Søren Mørch: Det store bankkrak. 1986, s. 46-48. 